\title{
Geography, capabilities and the educated person
}

\author{
David Lambert ${ }^{1}$ \\ Professor of Geography Education, UCL Institute of Education, London, UK
}

\section{Introduction}

This chapter introduces the GeoCapabilities project (www.geocapabilities.org) to explore school geography's contribution to citizenship education. This was a three-year EU funded project ${ }^{2}$ which finished its funded work in early 2017, although its ideas will continue to evolve because it has built considerable and widespread momentum internationally with associate partners across Europe, USA, China, Japan and Australasia. The project was oriented on developing leadership capacity in secondary school teachers of geography, focusing on the significance of teachers' 'curriculum making' responsibilities (Lambert and Biddulph, 2014; Lambert 2016). Led from London (UCL Institute of Education), and with a US Partner (the American Association of Geographers [AAG]) it draws strongly from Anglo-American traditions of curriculum studies and school level curriculum 'enactment' (Doyle \& Rosemartin, 2012) but has gained substantially from north European traditions of subject didactics (see Hudson 2016), working with the 'didactic triangle' and heuristic of subject, teacher and student.

The GeoCapabilities project is not explicitly concerned with citizenship education, still less about 'spatial citizenship' a term first coined by Thomas Jekel and colleagues (Gryl and Jekel, 2012). Spatial citizenship captures the importance of using spatial representations to develop competence with Geographical Information (GI) technologies, in order to participate effectively in society (Jekel, Gryl, and Schulze 2015; Schulze, Gryl and Kanwischer, 2015). The focus of GeoCapabilities is fairly and squarely on the role and purpose of geographical knowledge in relation to conceptions of the educated person (Lambert, Solem and Tani, 2015). The two key ideas, then, are geography and education; and capabilities acts as a device for bridging between the two. However, the capabilities approach (Nussbaum and Sen, 1993; Nussbaum, 2013), which encourages us to think about education

\footnotetext{
${ }^{1}$ david.lambert@ucl.ac.uk

2 “GeoCap2 Teachers as Curriculum Leaders" 539079-LLP-1-2013-1-UK-COMENIUS-CMP/2013-3433
} 
in terms of its contribution to the 'beings and doings' of people, their agency and ultimately their freedom, can readily be aligned with concepts of citizenship education in its broadest sense. Elsewhere (Lambert 2013; Lambert, 2018) I have stressed the significance of geography education in developing global understanding, as a matter of human survival in the Anthropocene epoch.

\section{We live in interesting times}

The discussion offered in this chapter has been crafted in a manner that is highly conscious of the social, cultural, economic and political context in which it is written: the fine-grained context of 'this day and age'. The chapter is written in the UK in early 2017, shortly after the inauguration of a new President of the USA knowingly calling for 'America First', and the Brexit vote in the UK in 2016 won on the slogan 'taking back control'. Several European elections, notably in France and Germany, have featured strong 'anti-establishment' interests and the influence of various forms of alternative political voice. It is a period still less than a decade on from the Global Financial Crisis of 2008, the effects of which are still felt acutely by those at the sharp end of 'austerity' (especially those reliant on public money), and which has convulsed politics with shock and unpredictability. The so-called Arab Spring, following the popular overthrow of the government of Tunisia in January 2011, the aftermath of Western policies in the Middle East (especially the Iraq war of 2003-11) and conflicts elsewhere in northern Africa (not to mention the effects of climate change exacerbating drought in, for example, Somalia) have fueled enormous migration pressures in Europe which have clearly also shocked the system of open borders between EU states. As I write, headlines point to the rise in nationalism across Europe: for instance, the impact of an openly racist 'Freedom Party' influencing the Dutch elections and shaking up the hitherto sturdy concept of Dutch liberalism with talk of banning the Koran and closing mosques. The possibility of Scotland seceding from the UK (the openly expressed goal of the devolved government in Edinburgh) is not based on racism and xenophobia but is nevertheless part of the trend to reassert national and regional identity which, as discussed by Painter (2008), began before the Euro crisis from which some countries such as Greece, Italy and Spain have suffered so acutely.

There is evidence to show that political instability and the rise in the appeal of strong or charismatic figures often resorting to tried and tested populism may be the result of a longer-term breakdown of trust in democratic processes. Indeed, recent global polling shows a decline in the belief that living in a democracy is thought to be essential (Foa and Mounk, 2017). Such hesitancy, especially among the young, may have led to a 'deconsolidation' of democracy in nations such as far apart as Venezuela and Poland. This trend has been coupled with a rise in the share of citizens wishing for a strong leader "who does not have to bother with elections" (ibid. p. 7). These are the circumstances that have been exploited by individuals, from Putin in Russia to his admirer in the USA the avowed non-politician Trump, both of whom have taken on the media and the judiciary and moved to consolidate power within the executive. And as Foa and Mounk observe, 
“The success of Donald Trump and his fellow populists ... is not a temporary or geographic aberration. Nor is it certain to trigger self-correcting mechanisms that will return the political system to the stability of a bygone era." (ibid. p. 8)

Among the populations of democratic states, including those completing their formal education, there may be confusion about how representative democracy works in its many forms, as well of a lack of understanding about alternative forms of government. In addition, in the context of the Brexit fantasy that leaving the EU will enable the UK to 'take back control', and Trump's nativist echo of the $1930 \mathrm{~s}^{3}$, the significance of post-1945 supra-national achievements may also be poorly understood today. This is the world of the North Atlantic Treaty Organization (NATO), the United Nations (UN), World Trade Organization (WTO), International Monetary Fund (IMF), the World Bank and the most ambitious example of shared sovereignty, the European Union (which did not really come into being until the 1992 Maastricht Treaty). In the global context of catastrophic species loss, climate change, pollution, weapons of mass destruction (WMDs), global corporations, vast money flows, intricate trade arrangements and of course the mass movement of people and ideas, it seems that the populist appeal to retreat to national and even regional identities (defended by walls and fences) may be impossible to achieve - even if for some reason it was thought to be desirable.

Theories abound as to the cause of this loss of faith in democracy and in international institutions such as the EU on the one hand, and the rise of populist and nationalist leaders on the other. For instance, some analysts (Heartfield, 2013) have suggested that rejection of the EU is a healthy re-assertion of democracy, a reaction to the perceived 'soft coup' that put Brussels bureaucrats in a dictatorial position over member states (especially those with weaker economies such as Greece or Portugal). It seems even amongst geographers there are those who appear to fear the loss of 'sovereignty' in the modern interconnected world and have difficulty embracing the notion of shared sovereignty. One such is Alex Standish who in 2007 wrote:

"The elevation and conflation of the local and the global in the proposition "think global, act local' is implicitly a rejection of the national sphere. It represents a denial of the political system through which citizens currently express their collective will via political representatives: the national will as sovereign power in the international sphere. Therefore, not only is global citizenship disingenuous with regard to how the world currently operates (there is no world government, nor global body for citizens to hold to account), it is rejecting

\footnotetext{
3 In Trump's inaugural address he twice used the phrase "America First" - a phrase that has been considered toxic ever since its use by the 1930s movement, designed to accommodate Hitler and keep the US out of the war against Nazi Germany.
} 
collective interest as a means through which politics is conducted while offering no democratic alternative".

(Standish, 2007, p. xx)

We need carefully to consider this position, for later we read that global citizenship education "encourages deference to higher authority rather than independent political thought" (ibid, p. xx). A simple 'definition' of citizenship is concerned with the individual's relationship with the state. You are a citizen of a state, and citizenship is concerned with your relationship with the state and its legal, political and economic structures. By this definition, you cannot be a citizen of the world (cf Standish: 'there is no world government, nor global body for citizens to hold to account'). It is this that appears to drive Standish's instinct to reassert the significance of the nation: indeed, he has written two books on the subject (Standish, 2009; 2013). However, although national boundaries in today's world are without question important, to suggest that the nation is somehow the basic, 'natural' unit, immutable and (ironically?) the receptacle for 'independent political thought', seems simply out of date and out of step with many geographical perspectives, from Doreen Massey's insights on the global sense of place (Massey 2014) to Peter Taylor's theorising political geography and in particular the state and the scale of ideology (Taylor 1981, p 27).

Before we consider how geography in school can respond to these challenges and uncertainties, we should note another signal feature of our interesting times: the influence of technology. The internet, social media and other forms of computing power underpinning for example GI and GPS have all had extraordinary effects which can be judged to be at the same time enormously emancipating, and a tyranny. Everybody with access to a smart phone or computer and electricity has information at their fingertips and the power to communicate instantly. This may be a mixed blessing - enabling government by tweet, the spread of propaganda, falsehoods and lies which can seriously undermine expert or specialist authority (including school teachers perhaps). Society has only just begun to get to grips with this technological revolution and schools, being part of society, are in no better position. But it is a challenge that cannot be ignored. There is now much hyperbole about the importance of 'twenty-first century skills' and the replacement of obsolete school subjects with generic learning competences, much of which seems to be accepted without question. However, as Gert Biesta (2005; 2012; 2013) has explained so convincingly, the co-option of the school curriculum by mainly economic imperatives such as notions of 'work-ready' have led to the widespread replacement of a moral language of education with the stultifying and narrow language of learning. It seems clear that taken together the forces of economics and technological change have undermined belief in traditional forms of schooling - the final death knell of traditional banking models of education based of transmission of a pre-decided, 'given' knowledge canon. In itself, this is no bad thing - there have been great advances in our understanding of powerful, social pedagogies since the second half of the 
twentieth century. But the weak epistemological foundations of teaching have appeared to allow the leaching away any principled resistance to relativism and naive forms of social constructivism divorced from disciplinary thinking (Firth, 2011; 2013; 2014; 2018). As well as undermining teaching, postmodern relativism has eroded faith in expert, scholarly knowledge, a trend even taken up cynically by some politicians who would rubbish experts encouraging the view that everyone's opinion and judgments are of equal worth and that ignorance (see John Morgan, 2017, for an interesting discussion of geographical ignorance) is an acceptable basis for making decisions.

To conclude this section, there is one final comment to make - as if we did not have enough to worry about. None of my introductory remarks, apart from a passing reference to the Anthropocene, have so far ventured anywhere close to the really big one - the bottom, bottom line so to speak - which is the environment. Despite remnants of climate change denial, including in the USA where the current President has characterized climate change to be a Chinese hoax and part of 'fake news', there is no denying the geographical challenges which face any young person growing up today. For instance, possibly hundreds of millions of people will be displaced as a result of rising sea levels and advancing desertification: can 'we' in less vulnerable places live comfortably in this knowledge? But in addition, we know that the oceans are also being poisoned by plastic and urban air quality has been impaired to dangerous levels by the burning of fossil fuels in motor cars. Whether we can rely on technocratic fixes for these issues or not, these are global pressures which form the backdrop of growing up in this day and age. What are the educational implications? And what is the role of geography as a component of the school curriculum?

\section{GeoCapabilities: framing the geography curriculum}

The GeoCapabilities project begins with the question: who are the young people we teach? This is the prior question to why we would teach them geography (and what we should teach them, and how). This question requires us to think about the circumstances in which young people are growing up. The question requires us to respond to the challenges discussed in the previous section and to say what young people need in order to face the future with some confidence. That is to say, in what ways do we think young people should be equipped with knowledge and an enhanced intellectual capacity to think and imagine their place in the world? There are many different ways to answer this, for the case can easily be made that young people need scientific knowledge, historical perspectives, artistic

\footnotetext{
${ }^{4}$ This is another phrase that seems consciously to take us back to the mid-twentieth century and that previous period of economic uncertainty and loss of faith in democracy. Hitler frequently referred to the Lügenpresse (lying press) in the 1930s, a part of the conspiracy that he convinced his followers he was fighting against on their behalf.
} 
imagination and access to many other forms and field of thought. GeoCapabilities simply makes the case that within the mix geographical knowledge and thought is a key component.

The GeoCapabilities approach contrasts with other very influential trends in education (Hazel, 2017). For example, the Organisation of Economic Cooperation and Development (OECD) has responded to internationally felt pressures to reform education by proposing to test a set of 'global competences' in the next round of the Programme of International Student Assessment (PISA) in 2019. Andreas Schleicher, the OECD's director of education and skills, explained that such competences would encourage teachers in school to show children how to recognise 'fake news' by testing their analytical and critical skills. These are posited as generic skills which, presumably, he believes are not currently taught effectively enough in schools today. However, the limitation of Schleicher's position is its strong tendency to undermine the role of subjects in the school curriculum. The very origin of the subject disciplines was to question orthodoxies and sometimes superstitions about how the world works: the sciences, geography, history (and other subject specialisms) have developed through focussing analytical and critical thought. They have developed distinctive perspectives, methods and ways of thinking (such as Susan Hanson (2004) has tried to identify in geography as the 'geographic advantage'). In searching for better knowledge and more truthful accounts the disciplines are never static nor fixed, but dynamic and evolving. The capabilities approach is therefore quite distinctive from the OECD's competence based approach: it requires us to think about the purpose of subjects in schools and not dismiss them merely as given 'contents' and by implication an impediment for what is valuable in the educative process (such as critical thinking). School subjects in the context of the specialist disciplines that produce them embody forms of critical thinking.

In his final volume of work Basil Bernstein (2000) argued for the 'pedagogic rights' of young people to individual enhancement, social inclusion and political participation (see also McClean et al 2013). These 'rights' are expressed as outcomes of educational processes and are strikingly similar to the notion of capabilities as developed in the GeoCapabilities project (Solem, Lambert and Tani, 2013; Lambert, Solem and Tani, 2015). For Bernstein, access to knowledge is the key educational contribution to fighting the inequalities of educational outcomes, or as we argue here, in preventing capabilities deprivation. It is for this reason that Michael Young's development of the helpful concept of 'powerful knowledge' (Young, 2008; 2013; 2014) has been conceptually significant in the GeoCapabilities project. In direct opposition to those who urge a skills-based curriculum based on imparting generic 'competences' (often deemed especially appropriate to 'less academic' students), Young and colleagues argue that it is a matter of social equity that all young people have the right to be introduced to powerful - or disciplinary - knowledge, for this provides the building blocks for a high quality general education. Young has developed a social realist position, usefully discussed by Roger Firth in the context of the geography curriculum in English schools (Firth, 2011; 2013), which counters both the extreme relativist positioning of much 'progressive' skills-led thought in education 
and those who propose ultra 'traditionalist' knowledge-led perspectives, who see the contents of the school curriculum as a fairly fixed selection or canon of 'core knowledge' (Hirsch, 1987; 2007). Hirschian 'core knowledge' is limited. Whilst it appears to value the accumulation of facts, powerful knowledge stresses the systematicity of knowledge - how it links and builds, and how it can be tested and given warrant. The social realist position promotes a progressive knowledge led curriculum.

In an attempt to develop the idea of a progressive, knowledge-led curriculum, Young and Muller (2010; 2016) have introduced an extremely helpful 'Three Futures' heuristic (See Figure 1). 'Future 3' (F3), which is underpinned by powerful disciplinary knowledge, has become a key element in GeoCapabilities project, the extent to which the project encourages the realisation of an F3 geography curriculum. An essential element to this, and the debate which a capabilities perspective opens up, is to clarify ways in which geographical knowledge in the curriculum can be considered to be 'powerful knowledge'. Following Alaric Maude's analysis of Young's writings (Maude, 2016), the power of knowledge depends mainly on what the knower can do with it: it resides in their enhanced capacities to think (see Figure 2). Putting the 'geo' into GeoCapabilities, therefore, is concerned with specifying the essential contribution geographical knowledge makes to the education of all young people: to be able to think geographically (I have elsewhere (Lambert 2017), opened up the meaning of this for practitioners, albeit mainly for a UK context). Or put another way, how the realisation of an F3 curriculum, in which students interact effectively with powerful geographical knowledge, contributes in particular ways to enhancing their capabilities. It is important to realise the significance of F3 based upon the acquisition of powerful geographical knowledge. F3 is not some 'middle way' combining the inadequacies of both F1 and F2. It is a way of thinking about the curriculum as experienced by the students in which epistemic quality - the quality of what is being taught - is paramount. It is not an overstatement to suggest that in both F1 and F2 teachers can abrogate responsibility for epistemic quality. Not so for F3.

\section{<FIGURE 1 HERE>}

\section{Geographical knowledge and the teacher}

Young people who do not have access to powerful geographical knowledge, maybe because geography is not even offered as part of the curriculum or because they are taught by ill-prepared teachers, are, according to the capabilities approach outlined earlier in this chapter, deprived or diminished in certain aspects of their human potential. GeoCapabilities argues that to deprive children access to powerful disciplinary knowledge (possibly children considered to be 'less academic' or more suited to developing practical skills) undermines their capabilities as citizens and as human beings. 
If this sounds like an overreaching claim then remember that the capable citizen is not only a person armed with information, 'competence' and a marketable skill-set. Capability is, we argue, also tied up in a person's capacity to think (see Figure 2), to use, and to apply knowledge in their encounters with the world (its social, cultural, economic, environmental and political dimensions). This is what the Geographical Association, in its 2009 'manifesto', referred to as geography's potential to enable autonomous thought and for young people to gain 'a different view' of themselves in the world (GA, 2009). GeoCapability, then, is heavily reliant upon the acquisition and development of powerful geographical knowledge and the profound questions this raises for teachers have both a curriculum and pedagogic dimensions. What is it you are teaching, and in what manner are you teaching it, so that it contributes to your students' acquisition of powerful geographical knowledge?

\section{$<$ FIGURE 2 HERE>}

Powerful disciplinary knowledge (PDK) is thus specialized knowledge and exists beyond the everyday experience of people. It is often abstract, being theoretical or conceptual, but it is enabling. The GeoCapabilities project developed a method to engage teachers with the kind of thinking they must undertake in order to identify (and prioritise) the powerful disciplinary knowledge in what they teach. This method is to write PDK 'vignettes', several examples of which are found on a Story Map (also accessed through Module 1 of the GeoCapabilities website ${ }^{5}$ ). An example of powerful geographical knowledge fully illustrated on the GeoCapabilities website is what Doreen Massey (2014) referred to as a "sense of the global", not just in the everyday sense of mediated images through film, music and fashion, but in the counterintuitive sense of the planet as a single entity or place, with all the physical and human interdependencies that make it so. Armed with a global conception of place - of places as meeting points with porous boundaries through which phenomena of all kinds flow (rather than discrete entities with firm boundaries than can be sealed) - we have the means at least to doubt simple political messages about 'taking back control'. This global sense of place is illustrated by Massey in her 'three-minute essay' shown in Figure 3 and featured in GeoCapabilities Module 1. A strong sense of the global is derived from powerful geographical knowledge that is available to all - if there are specialist teachers equipped and available to teach it.

If a F3 geography curriculum as advocated here has any single metaphorical tone it is 'engagement', not 'delivery'. The key outcome then is not to transfer into the heads of young people a list of facts (or indeed theories or models presented and learned as if they were facts). Likewise, the key attribute of an educated person is not simply to recall such facts accurately in a quiz or test, for although this

\footnotetext{
${ }^{5}$ http://www.geocapabilities.org/training-materials/module-1-the-capabilities-approach/intopractice/
} 
may well denote an impressive ability it does not necessarily provide much evidence of a person's capacity to think or reason. The knowledge-led curriculum proposed here is therefore not to be confused with some versions of knowledge orientation such as Hirsch's well-known and influential promotion of core knowledge, which does indeed seem to reduce geography to a list of essential facts. An F3 curriculum certainly does not ignore facts, but, like Massey, places the facts into a conceptual frame that enables deeper understanding of their relationship. An F3 curriculum would not simply deliver Massey's essay, but ask students to interrogate it.

\section{$<$ FIGURE 3 HERE >}

Just as we have to be careful not to confuse a knowledge-led curriculum with the delivery of predetermined facts, we also have to exercise some care with the idea of engagement. 'Learning by doing' has had a long history of thought and practice in western education systems and, although clearly very difficult to implement meaningfully, has reached the point of general orthodoxy amongst educationists and policy makers. Thus, today in the UK, teachers (who are under scrutiny as never before) are now castigated for talking too much in class; frequently, they are told that classrooms should be 'active' instead. Pedagogy (how shall we teach this?) is therefore privileged to a degree that places it in an inappropriate relationship to curriculum, so that questions of 'fitness for purpose' do not even get asked. This is the apotheosis of 'learnification' (Biesta, 2012; 2013) where the acquisition of the predominantly soft skills of 'learning to learn' becomes the vague and inadequate justification for sending children to school.

My use of 'engagement' therefore is not meant to conjure images simply of busy classrooms. Active learning can be meaningless unless the activity is fit for purpose - is enabling access to and the development of a powerful generalization, concept or idea. A F3 'curriculum of engagement' is one in which both teachers and students are interested (perhaps for different reasons) in notions of better knowledge. To create better knowledge is what the disciplines are for, and in saying this we can quickly acknowledge that such knowledge is always open to contest, being contingent on new findings or fresh theoretical developments. Better knowledge is clearly always in a state of becoming; it is developing and dynamic, and for this reason teachers and their students need in some way to be engaged with it. For example, the human backstory of continental drift as a theory, and the subsequent development of plate tectonics (Hawley and Lyon, 2017) provides a fine example of specialist knowledge production: of how orthodox views can be overturned by argument, evidence and imagination.

\section{Capabilities, geography and the educated person}

I acknowledge that a capabilities approach may not at first glance suggest a knowledge-led curriculum 
(although the GeoCapabilities project bends over backwards to privilege specialist geographical knowledge). This is where Young and Muller's 'three futures' device (see Figure 1) is helpful in making some distinctions that not only show the place of knowledge, but the nature of knowledge in a progressive curriculum of engagement. This is one reason why Future 3 thinking has been taken up by the GeoCapabilities project as a means to support curriculum leadership in school geography internationally. It attempts to do this not by writing some kind of international charter or laying down an ideal curriculum, but by offering a framework to enable teachers to think about their work in enacting the curriculum, or as GeoCapabilities describes it, their curriculum making. Statements about educational outcomes, such as those we may wish for citizenship education, are frequently made in generic terms, as we have seen earlier in this chapter in the case of the OECD. Aims-led 'grand designs' of the curriculum often encourage this too, undermining subjects and thus promoting an F2 curriculum. Of course, such curriculum thinking was and is a response to the widely acknowledged deficiencies of F1. Such outcomes-led curricula, though well-intentioned, are an inadequate response to the limitations of F1 owing to their seemingly careless disregard for knowledge as the foundational curriculum principle 6 . This is akin to "throwing the baby out with the bathwater". This section attempts to show briefly how a capabilities approach to curriculum thinking has the potential to help "bring knowledge back in" (Young 2008) and to develop a genuinely F3 curriculum.

Capabilities are not the same as general competences or free-floating critical thinking skills. Recent writing on the transformative potential of education has shown that this is based on the individual's acquisition of disciplinary knowledge: there is, for example, some empirical evidence from Higher Education to indicate that students value greatly the way such knowledge development enables them to think more broadly about the world (McLean et al 2011; 2013). Furthermore, induction into disciplinary knowledge or a specialism may provide aspects of what Martha Nussbaum calls the capability of "affiliation". It is, according to Nussbaum (2000: 82), to "behave in an incompletely human way" if a person thinks about the world and their place in it as if only their views and experience mattered. Disciplines provide a way to enter complex forms of discourse and perspectives that have arisen in communities using procedures of argument and contestation. This includes abstract and theoretical knowledge which by definition is beyond the experience of the everyday. As we are initiated into disciplines we gain access to some of the excitement - and the significance - of knowledge creation (a combination of 'knowing that' and 'knowing how' in specialist communities or disciplines). We can become deeply committed to what it means to be, or to think like, a historian, a mathematician, a musician ... or a geographer. Such initiation into disciplinary thought is of great value and, as we argued in the previous section, should be available to all young people (and not only

\footnotetext{
${ }^{6}$ In the British context the Royal Society for the Arts (RSA) "Opening Minds" curriculum would be a good example: http://www.rsaopeningminds.org.uk/.
} 
those who go to university): all have the right to the capabilities offered through such "epistemic ascent" (Winch 2013).

The GeoCapabilties project explored the potential of the capabilities approach to express the "power" of geography as a school subject (Lambert, Solem and Tani, 2015). In doing this we hope to provide a deeper theoretical basis for teachers' curriculum making and indeed, the part curriculum making should play in teachers' work (see GeoCapabilities Module $2^{7}$ ) Following Walker and Boni (2013), the project therefore argues that the capabilities approach can expand and deepen the conceptual language of teaching and curriculum at high school level. The project purports to show that the notion of 'GeoCapabilities' helps connect a progressive form of discipline-oriented geography teaching to the context of broad educational aims. In so doing it enables an F3 curriculum.

As we saw earlier, the prominent geographer Doreen Massey has recently argued that geography is a discipline that helps us "take on the world" (2014: 202) by revealing the concept of the planet as a whole and the realization that every locality on Earth is connected to global processes. In a different way and in the context of understanding cities, Andrew Kirby (2014) has made a different case for geography as powerful knowledge, this time based on an idiographic understanding of place contexts (in preference to the roughshod application of nomothetic principles and processes). The two approaches are reconcilable and the relational understanding that results forms a substantial element of what it means to 'think geographically'. Thus, powerful knowledge in geography (as in any subject) cannot be itemized in Hirschian lists which claim to embrace the geography that children 'need to know'. Although a summary of powerful knowledge in geography may legitimately reference the importance of geographical 'facts' (referred to metaphorically by the Geographical Association as the subject's 'vocabulary'; also, see Lambert, 2011a: 251), it should mainly emphasize the acquisition and development of systematic conceptual knowledge that informs geography's "relational understanding" - that is, metaphorically, the subject's 'grammar'. Here we are referring to what are sometimes called geography's 'big ideas' or 'key concepts' rather than a long list of substantive concepts such as city, river, industrial location etc. Geographers argue about what these are and both Brooks (2013) and Taylor (2008) provide an introduction to some of the disputes. Even so, there is some international stability and agreement that geography is concerned principally with place, space and environment (occasionally scale is added) - these are complex and dynamic ideas which have evolved markedly with the development of geography as a discipline, and which will continue to do so.

\footnotetext{
${ }^{7}$ http://www.geocapabilities.org/training-materials/module-2-curriculum-making-byteachers/aims/
} 
In addition, powerful disciplinary knowledge should (crucially) include a third element, which we could refer to as 'procedural knowledge', referred to in Figure 1 as epistemic processes - how a discipline provides warrant. This may also include a range of skills used widely in geography such as how to analyze spatially referenced data using maps and GIS for example. Such skills (which, of course, are not unique to geography) are not to be taught as ends in themselves: they are to be used self-consciously and critically, and within the intellectual context of searching for meaningful distinctions and applying defensible conclusions to geographical enquiries in real world contexts. In schools, good teachers do this through the judicious use of powerful pedagogies (Roberts 2014). Margaret Roberts' important book (Roberts, 2013) on enquiry pedagogies in geography provides a theoretically robust but practical guide on how to engage students both with data and ideas.

Expressed like this, 'procedural knowledge' assumes particular significance, even providing a glimpse of how geographical knowledge has been (and continues to be) produced. One can imagine the power of introducing students - even young students - to disciplinary narratives: for example, of how the idea of continental drift was established; how environmental determinism was roundly rejected; how (and why) urban land use models have been produced; the attraction (and dangers) of simple demographic transition models or push-and-pull theories of migration, of stages-of-growth approaches to development ... we could go on. But the general point to emphasize is that geography pulls on its 'vocabulary and grammar' in order to make provisional and contingent sense of the world. This almost inevitably includes a futures dimension - a consideration of how the world may become.

Thus, in the terms I have outlined here, teaching geography well (that is, with an F3 curriculum mindset) is a demanding task, and requires highly developed curriculum making abilities. Effective curriculum making depends on a range of professional knowledges as we have seen, but especially a grasp on how geography can be thought of as powerful knowledge - plus the pedagogic skills to convey this. Through the GeoCapabilities project we have attempted to summarize powerful knowledge in geography as consisting of:

- the acquisition and development of deep descriptive and explanatory "world knowledge"; this may include (for example) countries, capitals, rivers and mountains; also world wind patterns, distribution of population and energy sources. The precise constituents and range of this substantive knowledge is delineated locally and influenced by national and regional cultural contexts.

- the development of the relational thinking that underpins geographical thought; this includes place and space (e.g. the local and the global), the human and the physical and notions of environmental interdependence and interaction. This knowledge component is arguably more independent of local circumstances and influences, being derived from the discipline: concepts like place, space and environment are complex, evolving and contested and, 
referring back to our earlier metaphor, can be thought of as fundamental components of geography's syntax. They are sometimes referred to as geography's "big ideas", "key concepts" or "second order" concepts (see Brooks 2013 who refers to Taylor's (2008) ground clearing work on concepts in school geography).

- a propensity to apply the analysis of alternative social, economic and environmental futures to particular place contexts; this draws on a range of skills developed through appropriate pedagogic approaches such as decision-making exercises; in addition to intellectual skills such as analysis and evaluation this also encourages speculation, imagination and argument (see Hicks, undated). If we accept that it is what students are then able to do (including, to think in new ways) that give geographical knowledge its "power", then this category of what we might think of as "applied geography" is crucial.

(adapted and developed from Lambert 2011a; 2011b; 2016; Solem, Lambert and Tani 2013)

Understanding geography in this way is not straightforward, for it is not easily derived from everyday experience and popular images of what is meant by the geographical. To organize teaching in a way that brings about powerful school geography requires what the GeoCapabilities project describes as specialist 'curriculum leadership', manifest through effective curriculum making. Module $2^{8}$ of the project introduces the practical device of using carefully chosen curriculum artefacts' as a way both to illustrate and enact curriculum making principles. The main audience of the GeoCapabilities website are trainers and teacher educators, particularly of specialist teachers who are (or have been) engaged with geographic disciplinary thought and knowledge to first-degree level. A subsequent development of the project will be to develop the capabilities approach and the specific training devices (the powerful knowledge 'vignettes' and the curriculum making 'artefacts') with non-specialist teachers of geography. The goal will remain the same - to improve the epistemic quality of geography taught in secondary schools

\section{Conclusion}

In this chapter, which draws heavily from the GeoCapabilities project, I have attempted to make the case for the role of high quality geography teaching in educating informed, autonomous and critical citizens ready for the challenges of his day and age. Unspoken along the way is my realization that there is in my discussion more than a hint of 'liberal education' and a focus of the educated individual - possibly redolent of a previous age. I make no apologies for calling for something from the spirit of the Enlightenment that informed that previous age. Even though in this day and age - of fast

\footnotetext{
${ }^{8} \mathrm{http} / / /$ www.geocapabilities.org/training-materials/module-2-curriculum-making-by-teachers/intopractice/
} 
capitalism and financial crisis; of environmental degradation and the threat of climate change; and of loss of trust in democracy and progress - we may seem to have different priorities from gentler times, I say the priorities remain constant. It is sometimes said, with some justification, that education provides no guarantees: as witnessed by the fact that the mid-twentieth century holocaust was propagated by the best-educated and most cultured European nation. But education is all we have. There were no gentler times. As the great English educationist Harold Rosen wrote, in his poem trying to situate himself in relation to the horrors of the Nazi genocide,

“... Are you too asking yourself

Why is there no blood on these sheets?

And how can we sleep with ghosts?"

$\mathrm{He}$ is asking that we remain alert, ask questions and perhaps, hone those intellectual skills that contribute to what Postman and Weingartner (1969) memorably called "crap detection". Education has many purposes and teachers get pulled all which ways. But somewhere in the mix is the need to enable children and young people, to detect crap or, as Basil Bernstein put it perhaps more elegantly, "to think the unthinkable and the not yet thought" (Bernstein, 2000, p 30). This refers to the Enlightenment idea that knowledge is the only real source of freedom. Unlike Postman and Weingartner, who were early Future 2-ists, the GeoCapabilities project has sought to show that informed, dynamic, critical thought can be accomplished when specialist subjects, including geography, are thought of in terms of their powerful knowledge and taught with appropriately powerful pedagogies. The capabilities approach encourages the claim that without powerful geographical knowledge an individual's education is significantly impaired. This chapter has tried to show precisely how and in what way.

\section{Acknowledgement}

The author would like to thank two anonymous readers of an earlier draft of this chapter. Their comments were most helpful, though of course any remaining deficiencies are all my own.

\footnotetext{
9 The final line of his poem "In the SS barracks, 1945". Printed in full in Richmond, 2017, p. 569)
} 


\section{References}

Bernstein, B. (2000) Pedagogy, Symbolic Control and Identity: Theory, Research, Critique (revised edition). London: Rowman \& Littlefield.

Biesta, G. (2005) Against learning. Reclaiming a language for education in an age of learning, Nordisk Pedagogik, 25, pp 54-66.

Biesta, G. J. J. (2012) 'Giving teaching back to education: responding to the disappearance of the teacher’, Phenomenology and Practice, 6(2): 35-49.

Biesta, G. (2013). Comment on Bill Boyle's Blog: 'The Importance of Teaching: Learnification part 2', Educarenow Retrieved from http://educarenow.wordpress.com/2013/03/09/the-importance-of-theteacher-learnification-part-2/

Brooks, C. (2013) 'How do we understand conceptual development in school geography?', in D. Lambert and M. Jones (eds.), Debates in Geography Education. London: Routledge. pp. 76-88.

Doyle, W. and Rosemartin, D. (2012) The Ecology and Curriculum Enactment: frame and task narratives, Interpersonal Relationships in Education Vol. 3, pp 137-147

http://link.springer.com/chapter/10.1007\%2F978-94-6091-939-8_9

Firth, R. (2011) Making geography visible as an object of study in the secondary school curriculum, Curriculum Journal, 22, 3, 289-316.

Firth, R. (2013) 'What constitutes knowledge in geography?', in D. Lambert and M. Jones (eds.), Debates in Geography Education. London: Routledge. pp. 59-74.

Firth, R. (2014) Constructing geographical knowledge, in Barratt, B. and Rata, E. (eds) Knowledge and the future of the curriculum. Basingstoke: Palgrave Macmillan, pp 53-66.

Firth, R. (2018) Recontextualising Geography as a School subject, in Jones, M. and Lambert, D. Debates in Geography Education $2^{\text {nd }}$ Edition, Abingdon: Routledge.

Foa, R.S. and Mounk, Y (2017) The Signs of Deconsolidation, Journal of Democracy, 28, 1, 5-15, accessed on line 15 March 2017:

http://www.journalofdemocracy.org/sites/default/files/02_28.1_Foa\%20\%26\%20Mounk\%20pp\%205$\underline{15 . p d f}$

GA (2009) A Different View, Sheffield: Geographical Association.

http://www.geography.org.uk/resources/adifferentview/

Gryl, I. and Jekel, T. (2012) Re-centring Geoinformation in Secondary Education: Toward a Spatial Citizenship Approach, Cartographica, 47, 1, 18-28. 
Hanson, S. 2004. Who are 'we'? An important question for geography's future. Annals of the Association of American Geographers 94 (4): 715-22.

Hawley, D. and Lyon, J. (2017) Plate update: refreshing ideas for teaching plate tectonics, Teaching Geography, 42, 1, 30-32.

Hazel, W. (2017) Pisa boss: Pupils 'should be taught to recognise fake news', Times Educational Supplement, 18 March 2017 https://www.tes.com/news/school-news/breaking-news/pisa-boss-pupilsshould-be-taught-recognise-fake-news (accessed 20 March 2017).

Heartfield, J. (2013) The European Union and the end of politics, Winchester: Zero Books.

Hicks, D. (undated) Teaching for a Better World: learning for sustainability http://www.teaching4abetterworld.co.uk/futures.html (accessed 21 March 2017).

Hirsch, E. D. (1987) Cultural Literacy: What Every American Needs to Know. New York, NY: Houghton Mifflin.

Hirsch, E. D. (2007) The Knowledge Deficit: Closing the Shocking Education Gap. New York, NY: Houghton Mifflin.

Hudson, B. (2016). Didactics, in Wyse, D., Hayward, L. and Pandya, J. (Eds) The Sage Handbook of Curriculum Pedagogy and Assessment, London: Sage.

Jekel, T., Gryl, I. and Schulze, U. (2015) Education for Spatial Citizenship, in Muniz Solari, O. et al (eds) Geospatial Technologies and Geographical Education in a Changing World, Cham: Springer.

Kirby, A. (2014) 'Geographic leadership, sustainability and urban education', Geography, 99(1): $176-82$.

Lambert, D. (2011a) 'Reframing school geography', in G. Butt (ed.), Geography, Education and the Future. London: Continuum. pp. 127-140.

Lambert, D. (2011b) 'Reviewing the case for geography and the 'knowledge turn' in the English national curriculum', Curriculum Journal, 22(2): 243-64.

Lambert, D. (2013). Geography in schools and a curriculum of survival, Theory and Research in Education, 11, 1, 85-98.

Lambert, D. (2016) Chapter 25: Geography, in Wyse, D., Hayward, L. and Pandya, J. (eds) The Sage Handbook of Curriculum, Pedagogy and Assessment, London: Sage Publications.

Lambert, D. (2017) Thinking Geographically, Jones, M. (Ed) Secondary Geography Handbook, Sheffield: Geographical Association.

Lambert, D. (2018) Towards a Future 3 Curriculum: the case of geography, in Guile, D., Lambert, D. and 
Reiss, M. (2017). Sociology, Curriculum Studies and Professional Knowledge: New Perspectives on the Work of Michael Young, London: Routledge.

Lambert, D., Solem, M. and Tani, S. (2015). Achieving Human Potential Through Geography Education: a capabilities approach to curriculum making in schools, Annals of the Association of American Geographers, 105, 4, 723-735.

Lambert, D. and Biddulph, M. (2014) The dialogic space offered by curriculum making in the process of learning to teach, and the creation of a progressive knowledge led curriculum, Asia Pacific Journal of Teacher Education, 43, 3, 210-224.

Massey, D. (2014) 'Taking on the world', Geography, 99, 1, 202-5.

Maude, A. (2016) What might powerful knowledge look like? Geography, 101, 2, 70-76.

McClean, M., Abbas, A. and Ashwin, P. (2011) 'Pedagogic rights and human capabilities', paper presented at the Annual Conference of the Society for Research in Higher Education, Newport, Wales, 7-9 December 2011.

McClean, M., Abbas, A. and Ashwin, P. (2013) University knowledge, human development and pedagogic rights, in eds. A. Boni and M. Walker, (eds) Human development and capabilities: Reimagining the university of the twenty-first century. London: Routledge. pp 30-43.

Morgan, J. (2017) The making of geographical ignorance? Geography 102, 1,18-25.

Nussbaum, M. (2000). Women and human development. Cambridge: Cambridge University Press.

Nussbaum, M. (2013). Creating capabilities: The human development approach. Cambridge: Harvard University Press.

Nussbaum, M. and A. Sen. (1993). The quality of life. Oxford: Oxford University Press.

Painter, J. (2008) European Citizenship and the Regions, European, Urban and Regional Studies, $15,1,5-19$.

Postman, N and Weingartner, C. (1969) Teaching as a Subversive Activity, New York: Dell Publishing.

http://kairosschool.co.za/wp-content/uploads/2011/02/Teaching-as-a-Subversive-Activity.pdf

Richmond, J. (2017) Harold Rosen: Writings on life, language and learning 1958-2008, London: UCL IoE Press.

Roberts, M. (2013). Geography Through Enquiry, Sheffield: Geographical Association. 
Roberts, M. (2014) Powerful knowledge and geographical education, The Curriculum Journal, 25, 2 , 187-209.

Schulze, U., Gryl, I. and Kanwischer, D. (2015) Spatial Citizenship education and digital geomedia: composing competences for teacher education and training, Journal of Geography in Higher Education, http://dx.doi.org/10.1080/03098265.2015.1048506

Solem, M., Lambert, D. and Tani, S. (2013) 'GeoCapabilities: towards an international framework for researching the purposes and values of geography education', Review of International Geographical Education Online [RIGEO], 3(3): 204-9.

Standish, A. (2007) Geography used to be about maps, Whelan, R. (Ed) The Corruption of the Curriculum: London: Civitas.

Standish, A. (2009). Global Perspectives in the Geography Curriculum: reviewing the moral case for geography, London: Routledge.

Standish, A. (2013). The False Promise of Global Learning: why education needs boundaries, London: Continuum.

Taylor, L. (2008) 'Key concepts and medium-term planning', Teaching Geography, 33(2): 50-4.

Taylor, P. (1981) A Materialist Framework for Political Geography, Transactions of the Institute of British Geographers, 7, 1,15-34.

Walker, M. and Boni, A. (2013) 'Higher education and human development: towards the public and social good', in A. Boni and M. Walker (eds.), Human Development and Capabilities: Re-Imagining the University of the Twenty-First Century. London: Routledge. pp. 15-29.

Winch, C. (2013) 'Curriculum design and epistemic ascent', Journal of Philosophy of Education, 47(1): $128-46$.

Young, M. (2008). Bringing Knowledge Back In, London: Routledge.

Young, M. (2013). Overcoming the crisis in curriculum theory: a knowledge based approach, Journal of Curriculum Studies, 45, 2: 101-118.

Young, M. (2014) Powerful knowledge as a curriculum principle, in Young, M. and Lambert, D. (with Roberts, C. and Roberts, M) (2014). Knowledge and the Future School: curriculum and Social Justice, London: Bloomsbury. Pp 65-88.

Young, M. and Muller, J. (2010). Three Educational Scenarios for the Future: lessons from the sociology of knowledge, European Journal of Education, 45, 1, 11-27.

Young, M. and Muller, J. (2016) Curriculum and the Specialization of Knowledge, Abingdon: Routledge. 
